\title{
Environmental Effect of Gas Flaring on the Soil pH Value in Some Communities in Niger Delta of Nigeria
}

\author{
Obi E. O., Osang J. E., Pekene D. B. \\ Department of Physics, Cross River University of Technology, Calabar, Nigeria
}

Email address:

emmanuelobi57@gmail.com (Obi E. O.)

\section{To cite this article:}

Obi E. O., Osang J. E., Pekene D. B. Environmental Effect of Gas Flaring on the Soil pH Value in Some Communities in Niger Delta of Nigeria. American Journal of Physics and Applications. Vol. 4, No. 6, 2016, pp. 158-164. doi: 10.11648/j.ajpa.20160406.14

Received: November 15, 2016; Accepted: November 29, 2016; Published: January 4, 2017

\begin{abstract}
This paper presents the environmental effects of gas flaring on $\mathrm{pH}$ values of the soil and rain water in some areas in Niger Delta. Different soil samples and rain water at various proximities from the gas flaring locations were taken. The samples collected were evaluated to determine the $\mathrm{pH}$ values of rain-water and that of the soil in the area under investigation. The result obtained shows a remarkable trend as the values of the $\mathrm{pH}$ of the soil and that of the rain water increased as we moved away from the gas flaring stations. The $\mathrm{pH}$ actually changed from extreme acidic $(3.5$ - 4.4) to moderate alkaline (7.9 8.4) as we moved away from the flaring points. The $\mathrm{pH}$ values tend to normalize at distances of more than $2 \mathrm{~km}$ away from most of the gas flaring points. The low $\mathrm{pH}$ values imply that there is formation of acid rain which has dangerous consequences on the environment and on the plants and animals. The resultant health implications of extreme acidity in the rain water and consequently in the soil was also discussed.
\end{abstract}

Keywords: pH Values, Acid Rain, Environmental Effects, Gas Flaring, Dangerous Consequences

\section{Introduction}

$\mathrm{pH}$ is the measure of acidity or alkalinity of a solution. It is a measure of the molar concentration of hydrogen ions in asolution. The letters PH stands for "power of hydrogen". It is defined as the negative base 10 logarithm of the molar concentration of hydrogen ions.

$$
\mathrm{pH}=-\log _{10}\left[\mathrm{H}^{+}\right]
$$

The $\mathrm{pH}$ value of any sample can be obtained by measuring the cell potential of that sample in reference to a standard hydrogen electrode. Gas flaring increases the amount of hydrogen ions in the atmosphere. Consequently, the rain water that comes from the atmosphere which has an increased amount of hydrogen ions will certainly have an increased amount of hydrogen ions. Furthermore, when the rain falls on the ground, it increases the amount of hydrogen ions in the soil.
Gas flaring is the burning off of gas into the atmosphere. The gas that would have been otherwise used for useful purposes is wasted by burning. Natural gas is a subcategory of petroleum that is naturally occurring. It is a complex mixture of hydrocarbons with a minor amount of nonhydrocarbon gases [11]. The discovery and extraction of natural resources have brought different consequences to the countries that are endowed with such resources. [1]; [8]. In Nigeria, the discovering of crude oil was in 1958, while the extraction and gas flaring activities of these natural resource started since 196 [13]; [9]. The burning off of gas became illegal since 1984 and the Nigerian government has set up several deadlines to end the practice, but gas flaring continues till date [4]; [10].

According to World Bank records, Nigeria is among the highest gas flaring countries in the world, see fig. 1 below: 


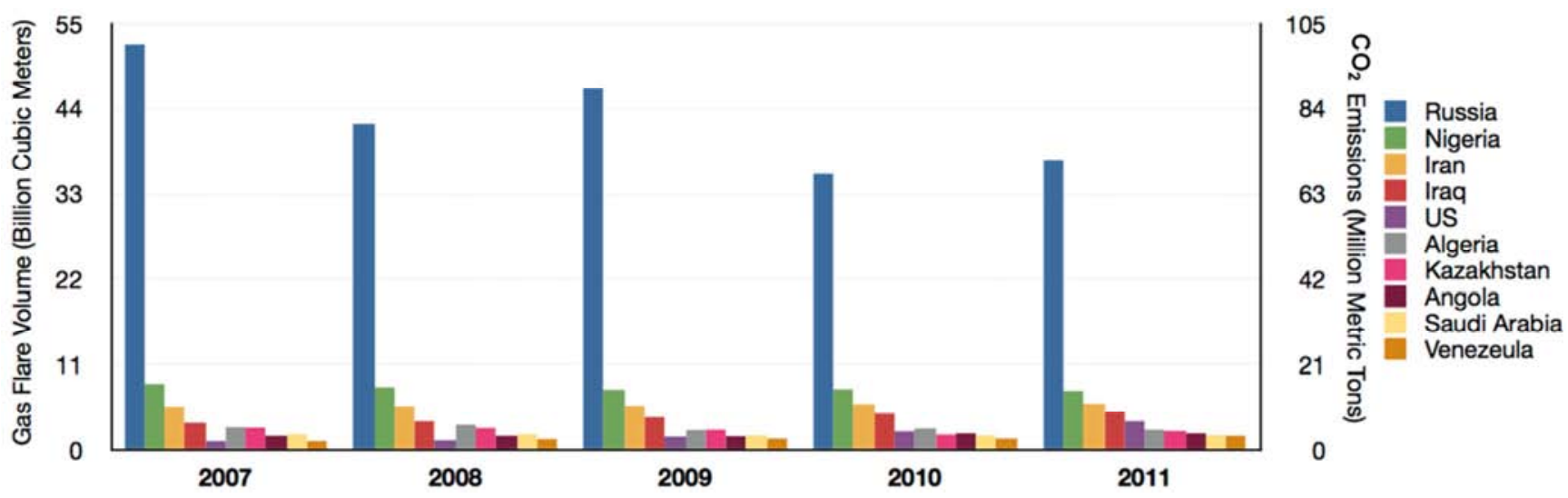

Fig. 1. 10 top countries that flare gas.

[7]; [10]pointed out that gas flaring is a major source of climate change which is creating increased uncertainty about the future temperature and precipitation in our environment. The smoke that comes from the gas flares contains sooty grey particles, and many invisible gases that can be very harmful to our environment. The flares from Nigeria alone have contributed large volumes of green house gases than any other Country in Africa. The flares have also released several dangerous toxins into the atmosphere, polluting the soil, atmosphere, water and the entire environment. Consequently, the health and well being of the nearby NigerDelta communities are adversely affected, exposing the residents to an increased risk of premature death, respiratory illnesses such as Asthora and cancers [5]; [6]. Gas flaring is the singular and most common source of global warming and contributes to emissions of carbon monoxide, nitrogen (II) oxide and methane which causes environmental pollution and ecological disturbances or destruction [1]; [2].

\section{Acid Rain}

Acid rainrefers to a mixture of deposited materials, both wet and dry, coming from the atmosphere containing more than normal amounts of nitric and sulfuric acids. In other word, Acid rain is a rain or any other form of precipitation that is unusually acidic, meaning that it possesses elevated levels of hydrogen ions (low $\mathrm{Ph}$ ). It can have harmful effects on plants, aquatic animals and infrastructure. Acid rain is caused by emissions of sulfur dioxide and nitrogen oxide, which react with the water molecules in the atmosphere to produce acids. Acidity is measured using a scale called the $\mathrm{Ph}$ scale. The $\mathrm{pH}$ scale ranges from 0 to 14 . A pH value of 7 is neutral, a $\mathrm{pH}$ less than 7 is acidic while a $\mathrm{pH}$ greater than 7 is basic [3]. The classification of $\mathrm{pH}$ values is given in the table 1 .

\section{Changes in Soil pH}

Research has shown that Soils tend to become acidic as a result of: (1) rainwater leaching away basic ions (calcium, magnesium, potassium and sodium); (2) carbon dioxide from decomposing organic matter dissolving in soil water to form a weak organic acid; (3) formation of strong organic and inorganic acids, such as nitric and sulfuric acid, from decaying organic matter and oxidation of ammonium and sulfur fertilizers. Strongly acid soils are usually the result of the action of these strong organic and inorganic acids.

The classification of soil $\mathrm{pH}$ values is given in the table 1 .

Table 1. Classification of soil $p H$ ranges.

\begin{tabular}{ll}
\hline Denomination & $\mathbf{p H}$ range \\
\hline Ultra acid & $<3.5$ \\
Extreme acid & $3.5-4.4$ \\
Very strong acid & $4.5-5.0$ \\
Strong acid & $5.1-.5 .5$ \\
Moderate acid & $5.6-6.0$ \\
Slight acid & $6.1-6.5$ \\
Neutral & $6.6-7.3$ \\
Slightly alkaline & $7.4-7.8$ \\
Moderately alkaline & $7.9-8.4$ \\
Strongly alkaline & $8.5-9.0$ \\
Very strong alkaline & $>9$ \\
\hline
\end{tabular}

Source: [12]

Lime is usually added to acid soils to increase soil $\mathrm{pH}$. The addition of lime not only replaces hydrogen ions and raises soil $\mathrm{pH}$, thereby eliminating most major problems associated with acid soils but it also provides two nutrients, calcium and magnesium to the soil. The addition of lime also makes phosphorus that is added to the soil readily available for plant growth and increases the availability of nitrogen. The increased amount of nitrogen hastens the decomposition of organic matter. Liming materials are relatively inexpensive, comparatively mild to handle and leave no objectionable residues in the soil. Some common liming materials are: (1) Calcic limestone which is ground limestone; (2) Dolomitic limestone from ground limestone high in magnesium; and (3) Miscellaneous sources such as wood ashes. The amount of lime to apply to correct a soil acidity problem is influenced by a number of factors, including soil $\mathrm{pH}$, soil texture (amount of sand, silt and clay), structure, and amount of organic matter. In addition to the soil variables the crops or plants to be grown influence the amount of lime needed. 
$\mathrm{pH}$ is of major importance in determining the corrosivity of water. In general, the lower the $\mathrm{pH}$, the higher the level of corrosion. However, $\mathrm{pH}$ is only one of the various factors affecting corrosion. Exposure to extreme $\mathrm{pH}$ values results in irritation to the eyes, skin, and mucous membranes. In sensitive individuals, gastrointestinal irritation may also occur. Redness and irritation of the eyes have been reported at $\mathrm{pH}$ values lower than 4 . The severity of the redness of the eyes increases with decreasing $\mathrm{pH}$. Damage to the epithelium is irreversible and extensive at $\mathrm{pH}$ below 2.5. In addition, $\mathrm{pH}$ can affect the degree of corrosion of metals as well as disinfection efficiency [3].

\section{Materials and Method}

\subsection{Data Source}

Visitations to the major communities in Rivers state that flare gas was done severally to ascertain any existence of common environmental hazards. Data was gathered from Different samples at various proximities from the gas flare locations. The research was done in MbodoAluu, Ogba-
Egbema-Ndomi, Eneka, Obio-Akpor and Omoku Communities in Rivers State, Nigeria. At each location, the soil $\mathrm{pHand}$ the $\mathrm{pH}$ of rain water was determined

\subsection{Rain Water pH Measurement}

Clean acid-free glass bottles were used to collect samples of rain water that had fallen during the preceding week. The samples were placed at distances of $200 \mathrm{~m}, 400 \mathrm{~m}, 600 \mathrm{~m}$ $800 \mathrm{~m}, 1000 \mathrm{~m}, 1200 \mathrm{~m}, 1400 \mathrm{~m}, 1600 \mathrm{~m}, 1800 \mathrm{~m}$ and $2000 \mathrm{~m}$ from the flare point. The funnel was covered with a plastic net to prevent the collection of windblown debris. Each bottle was placed on a stand $1.5 \mathrm{~m}$ above ground level. The collected samples were analyzed to determine the $\mathrm{pH}$ value of the collected water.

\section{Results and Discussion}

\subsection{Data Analysis}

The data collected is tabulated as shown in the tables below.

Table 2. The Average PH value of rainwater taken from gas flaringstation located at Ogba-Egbema-Ndomi Community River State, (April.2014 - Sept. 2014).

\begin{tabular}{|c|c|c|c|c|c|c|c|c|c|c|}
\hline \multirow{2}{*}{ Months } & \multicolumn{10}{|c|}{ Average $P H$ value } \\
\hline & $200 \mathrm{~m}$ & $400 \mathrm{~m}$ & $600 \mathrm{~m}$ & $800 \mathrm{~m}$ & $1000 \mathrm{~m}$ & $1200 \mathrm{~m}$ & $1400 \mathrm{~m}$ & $1600 \mathrm{~m}$ & $1800 m$ & $2000 \mathrm{~m}$ \\
\hline April & 4.5 & 4.7 & 5.0 & 5.5 & 5.3 & 5.4 & 5.4 & 5.4 & 5.5 & 5.9 \\
\hline May & 4.3 & 4.6 & 5.0 & 5.1 & 5.2 & 5.3 & 5.4 & 5.4 & 5.5 & 5.9 \\
\hline June & 4.1 & 4. 6 & 4.9 & 5.1 & 5.1 & 5.3 & 5.3 & 5.3 & 5.4 & 5.8 \\
\hline July & 3.9 & 4. 6 & 4.8 & 5.0 & 5.1 & 5.2 & 5.2 & 5.3 & 5.3 & 5.7 \\
\hline August & 3.7 & 4.5 & 4.8 & 4.9 & 5.0 & 5.1 & 5.2 & 5.3 & 5.3 & 5.7 \\
\hline September & 3.5 & 4.5 & 4.8 & 4.9 & 5.0 & 5.1 & 5.1 & 5.2 & 5.2 & 5.6 \\
\hline
\end{tabular}

Table 3. The Average pH value of rainwater sample taken from gas flaring station located at Eneka, Obio-Akpor Community River State,( April. 2014 - Sept. 2014).

\begin{tabular}{|c|c|c|c|c|c|c|c|c|c|c|}
\hline \multirow{2}{*}{ Months } & \multicolumn{10}{|c|}{ Average $\mathrm{PH}$ value } \\
\hline & $200 \mathrm{~m}$ & $400 \mathrm{~m}$ & $600 \mathrm{~m}$ & $800 \mathrm{~m}$ & $1000 \mathrm{~m}$ & $1200 \mathrm{~m}$ & $1400 \mathrm{~m}$ & $1600 \mathrm{~m}$ & $1800 \mathrm{~m}$ & $2000 \mathrm{~m}$ \\
\hline April & 4.9 & 4.9 & 5.0 & 5.4 & 5.4 & 5.4 & 5.5 & 5.7 & 6.0 & 6.2 \\
\hline May & 4.7 & 4.8 & 4.9 & 5.2 & 5.3 & 5.3 & 5.3 & 5.5 & 5.8 & 6.1 \\
\hline June & 4.7 & 4.8 & 4.8 & 5.0 & 5.1 & 5.3 & 5.3 & 5.4 & 5.7 & 5.8 \\
\hline July & 4.5 & 4.7 & 4.7 & 4.8 & 5.1 & 5.2 & 5.2 & 5.4 & 5.4 & 5.7 \\
\hline August & 4.1 & 4.1 & 4.5 & 4.7 & 4.7 & 5.1 & 5.1 & 5.3 & 5.3 & 5.5 \\
\hline September & 3.9 & 3.9 & 4.3 & 4.5 & 4.6 & 4.7 & 4.9 & 5.0 & 5.2 & 5.4 \\
\hline
\end{tabular}

Table 4. The Average PH value of rainwater sample taken from gas flaring station located at MbodoAluu Community River State, (April. 2014 - Sept. 2014).

\begin{tabular}{|c|c|c|c|c|c|c|c|c|c|c|}
\hline \multirow{2}{*}{ Months } & \multicolumn{10}{|c|}{ Average $\mathrm{PH}$ value } \\
\hline & $200 \mathrm{~m}$ & $400 \mathrm{~m}$ & $600 \mathrm{~m}$ & $800 \mathrm{~m}$ & $1000 \mathrm{~m}$ & $1200 \mathrm{~m}$ & $1400 \mathrm{~m}$ & $1600 \mathrm{~m}$ & $1800 \mathrm{~m}$ & $2000 \mathrm{~m}$ \\
\hline April & 5.2 & 5.3 & 5.3 & 5.3 & 5.5 & 5.8 & 5.9 & 5.9 & 6.1 & 6.2 \\
\hline May & 5.2 & 5.3 & 5.3 & 5.3 & 5.4 & 5.7 & 5.8 & 5.9 & 6.0 & 6.1 \\
\hline June & 5.1 & 5.2 & 5.2 & 5.2 & 5.2 & 5.4 & 5.6 & 5.8 & 5.9 & 6.0 \\
\hline July & 5.1 & 5.2 & 5.2 & 5.2 & 5.2 & 5.4 & 5.5 & 5.7 & 5.8 & 5.9 \\
\hline August & 5.0 & 5.1 & 5.1 & 5.2 & 5.2 & 5.3 & 5.3 & 5.5 & 5.7 & 5.7 \\
\hline September & 4.9 & 5.0 & 5.1 & 5.1 & 5.2 & 5.2 & 5.2 & 5.4 & 5.5 & 5.6 \\
\hline
\end{tabular}




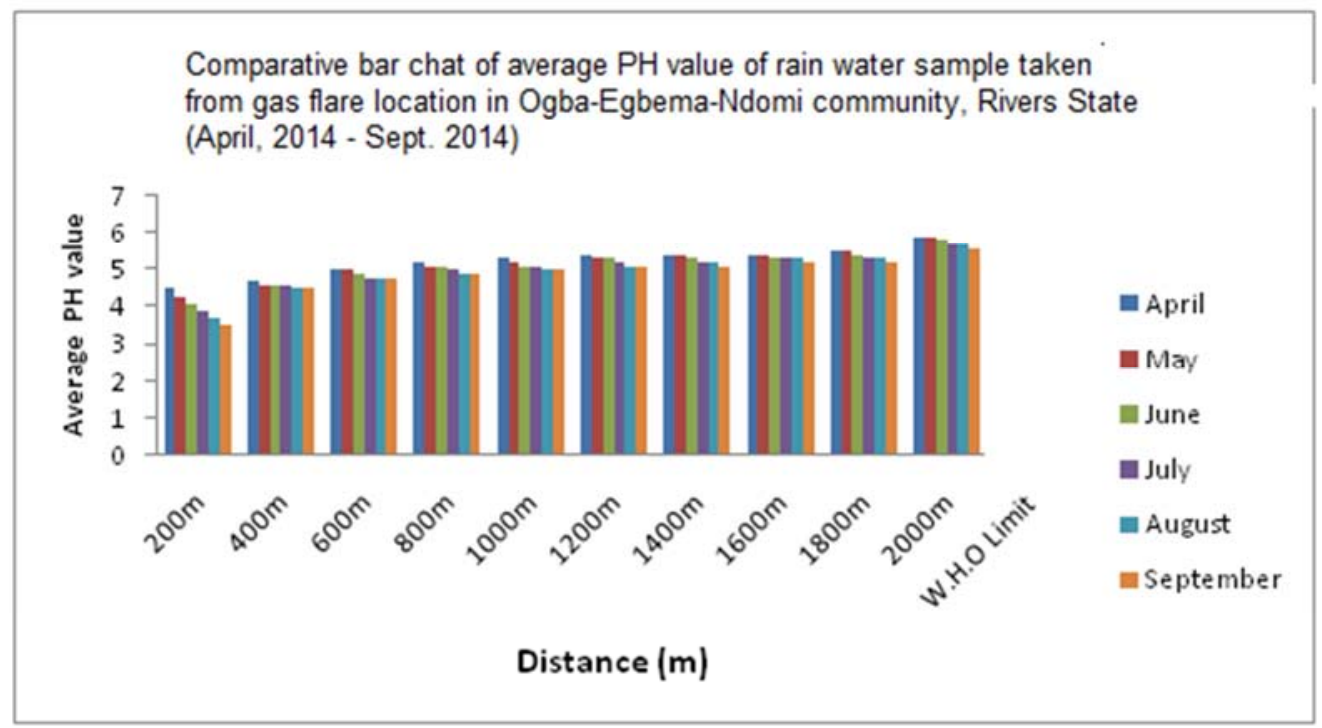

Fig. 2. Comparative Bar chat of Average pH value of rainwater sample taken from gas flaring station located at Ogba-Egbema-Ndomi Community River State, (April. 2014 - Sept. 2014).

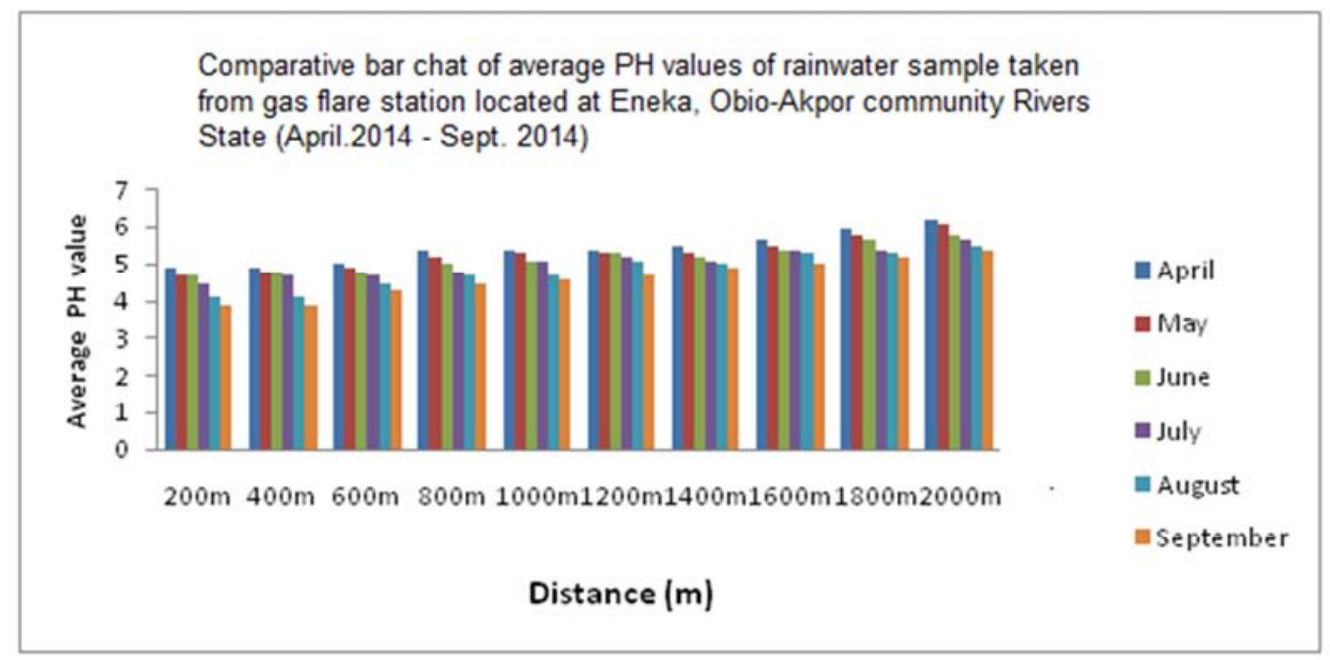

Fig. 3. Comparative bar chat of average PH value of rainwater sample taken from gas flaringstation located at Eneka, Obio-Akpor Community River State, (April. 2014 - Sept. 2014).

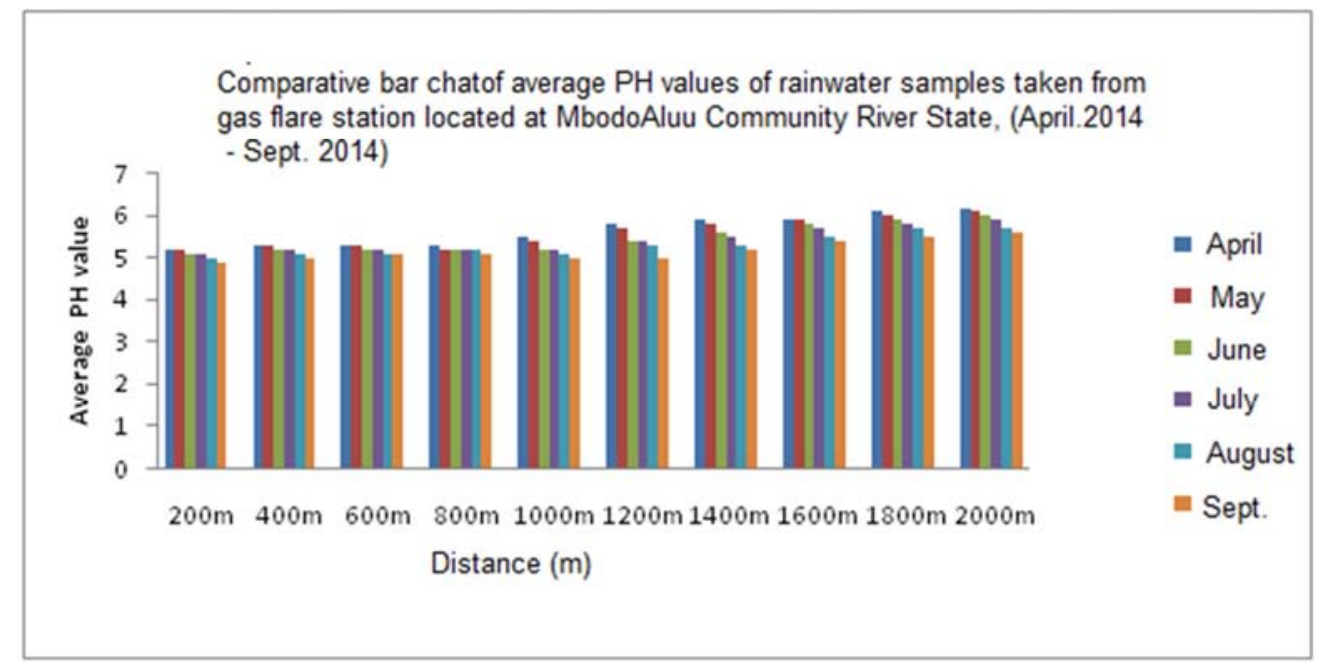

Fig. 4. Comparative Bar chat of Average pH value of rainwater samples taken from gas flaringstation located atMbodoAluu Community River State, (April. 2014 - Sept. 2014). 


\subsection{Soil pH Measurement}

The $\mathrm{pH}$ of the various soil samples taken from the same gas flare stations were determined from supernatant obtained from the mixture of the soil samples with sterile distilled de-ionized water. The samples were placed at distances of $200 \mathrm{~m}, 400 \mathrm{~m}$, $600 \mathrm{~m} 800 \mathrm{~m}, 1000 \mathrm{~m}, 1200 \mathrm{~m}, 1400 \mathrm{~m}, 1600 \mathrm{~m}, 1800 \mathrm{~m}$ and $2000 \mathrm{mfrom}$ the flare point. The $\mathrm{pH}$ was determined using a PYE UNICAM model $291 \mathrm{mkz} \mathrm{pH}$ meter with a combined glass electrode. The result is as presented below.

Table 5. The Average Soil pH Measurement taken from gas flaringstation in Ogba-Egbema-NdomiCommunity River State, (April.2014 - Sept. 2014).

\begin{tabular}{|c|c|c|c|c|c|c|c|c|c|c|}
\hline \multirow{2}{*}{ Months } & \multicolumn{10}{|c|}{ Average $P H$ value } \\
\hline & $200 \mathrm{~m}$ & $400 \mathrm{~m}$ & $600 \mathrm{~m}$ & $800 \mathrm{~m}$ & $1000 \mathrm{~m}$ & $1200 \mathrm{~m}$ & $1400 \mathrm{~m}$ & $1600 \mathrm{~m}$ & $1800 \mathrm{~m}$ & $2000 \mathrm{~m}$ \\
\hline April & 5.0 & 5.2 & 5.4 & 5.5 & 5.9 & 6.0 & 6.3 & 6.5 & 6.9 & 7.3 \\
\hline May & 4.9 & 4.9 & 5.3 & 5.4 & 5.7 & 5.9 & 6.1 & 6.1 & 6.6 & 7.1 \\
\hline June & 4.1 & 4. 6 & 5.3 & 5.3 & 5.5 & 5.6 & 5.9 & 5.9 & 6.5 & 6.7 \\
\hline July & 4.0 & 4.0 & 5.2 & 5.2 & 5.4 & 5.5 & 5.8 & 5.8 & 6.3 & 6.4 \\
\hline August & 3.8 & 4.5 & 5.1 & 5.1 & 5.3 & 5.4 & 5.5 & 5.5 & 5.9 & 6.0 \\
\hline September & 3.6 & 4.3 & 4.9 & 5.0 & 5.1 & 5.3 & 5.3 & 5.4 & 5.5 & 5.6 \\
\hline
\end{tabular}

Table 6. Average Soil pH Measurement taken from gas flare station located at Eneka, Obio-Akpor Community River State, (April. 2014 - Sept. 2014).

\begin{tabular}{|c|c|c|c|c|c|c|c|c|c|c|}
\hline \multirow{2}{*}{ Months } & \multicolumn{10}{|c|}{ Average $\mathrm{PH}$ value } \\
\hline & $200 \mathrm{~m}$ & $400 \mathrm{~m}$ & $600 \mathrm{~m}$ & $800 m$ & $1000 \mathrm{~m}$ & $1200 m$ & $1400 \mathrm{~m}$ & $1600 \mathrm{~m}$ & $1800 \mathrm{~m}$ & $2000 \mathrm{~m}$ \\
\hline April & 5.1 & 5.3 & 5.4 & 5.5 & 5.9 & 6.1 & 6.2 & 6.4 & 6.7 & 7.6 \\
\hline May & 4.4 & 5.1 & 5.4 & 5.4 & 5.7 & 5.8 & 6.1 & 6.2 & 6.4 & 7.1 \\
\hline June & 4.1 & 4.9 & 5.3 & 5.3 & 5.6 & 5.6 & 5.9 & 5.9 & 6.2 & 6.8 \\
\hline July & 3.9 & 4.8 & 5.2 & 5.3 & 5.4 & 5.5 & 5.8 & 5.8 & 6.1 & 6.5 \\
\hline August & 3.8 & 4.5 & 5.1 & 5.2 & 5.3 & 5.4 & 5.6 & 5.6 & 5.8 & 6.3 \\
\hline September & 3.7 & 4.5 & 4.9 & 4.9 & 5.1 & 5.2 & 5.2 & 5.4 & 5.5 & 5.8 \\
\hline
\end{tabular}

Table 7. Average Soil pH Measurement taken from gas flaringstation located at MbodoAluu Community River State, (April. 2014 - Sept. 2014).

\begin{tabular}{|c|c|c|c|c|c|c|c|c|c|c|}
\hline \multirow{2}{*}{ Months } & \multicolumn{10}{|c|}{ Average PH value } \\
\hline & $200 \mathrm{~m}$ & $400 m$ & $600 \mathrm{~m}$ & $800 \mathrm{~m}$ & $1000 \mathrm{~m}$ & $1200 \mathrm{~m}$ & $1400 \mathrm{~m}$ & $1600 \mathrm{~m}$ & $1800 \mathrm{~m}$ & $2000 \mathrm{~m}$ \\
\hline April & 5.4 & 5.5 & 5.7 & 5.8 & 6.1 & 6.2 & 6.4 & 6.7 & 7.0 & 8.8 \\
\hline May & 4.9 & 5.2 & 5.6 & 5.7 & 5.9 & 6.0 & 6.3 & 6.4 & 6.7 & 7.8 \\
\hline June & 4.6 & 5.1 & 5.5 & 5.5 & 5.8 & 5.9 & 6.1 & 6.2 & 6.6 & 7.5 \\
\hline July & 4.0 & 4.9 & 5.4 & 5.4 & 5.5 & 5.7 & 6.0 & 6.1 & 6.5 & 7.3 \\
\hline August & 3.9 & 4.8 & 5.2 & 5.3 & 5.4 & 5.5 & 5.7 & 5.9 & 6.0 & 6.8 \\
\hline September & 3.8 & 4.9 & 5.0 & 5.0 & 5.3 & 5.4 & 5.5 & 5.7 & 5.8 & 6.5 \\
\hline
\end{tabular}

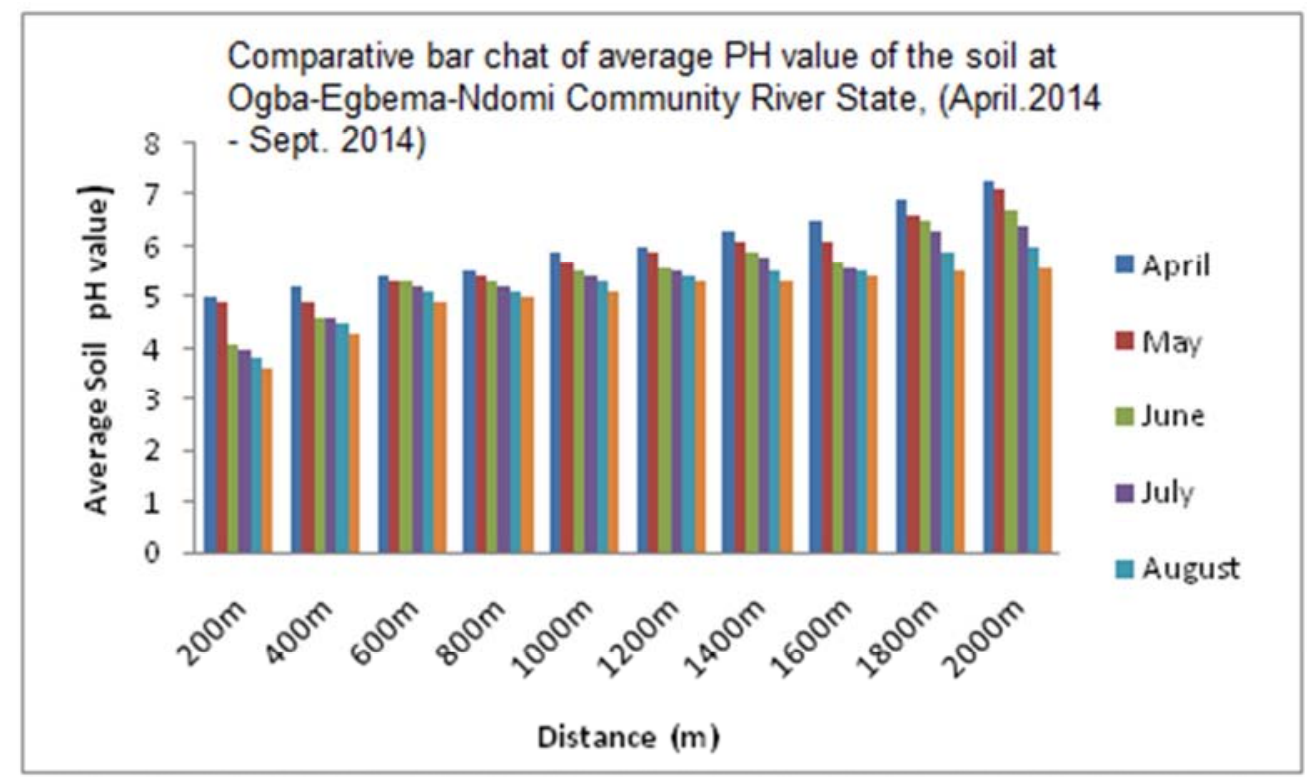

Fig. 5. Comparative Bar chat of Average pH value of the soil samples taken from gas flaring station located at Ogba-Egbema-Ndomi Community River State, (April. 2014 - Sept. 2014). 


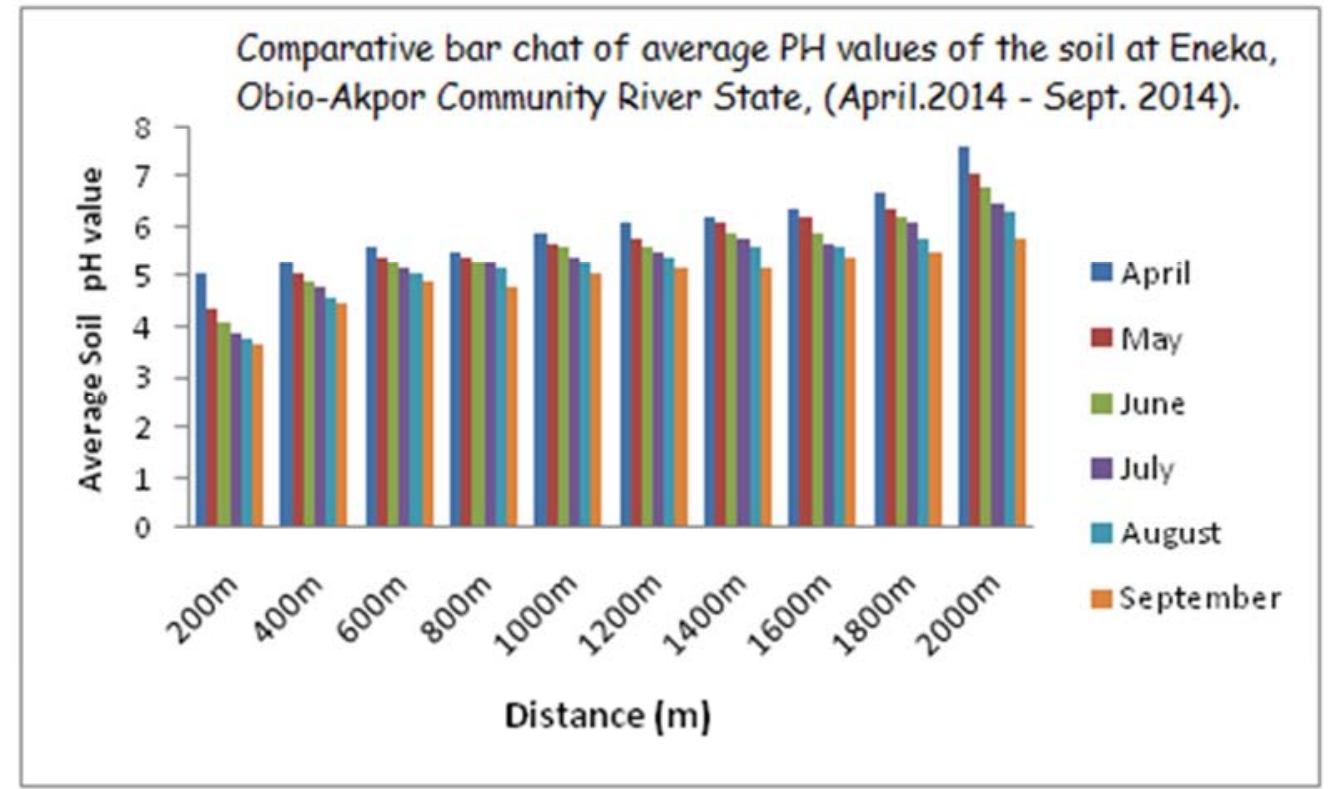

Fig. 6. Comparative Bar chat of Average pH value of the soil samples taken from gas flaring station located at Eneka, Obio-Akpor Community River State, (April. 2014 - Sept. 2014).

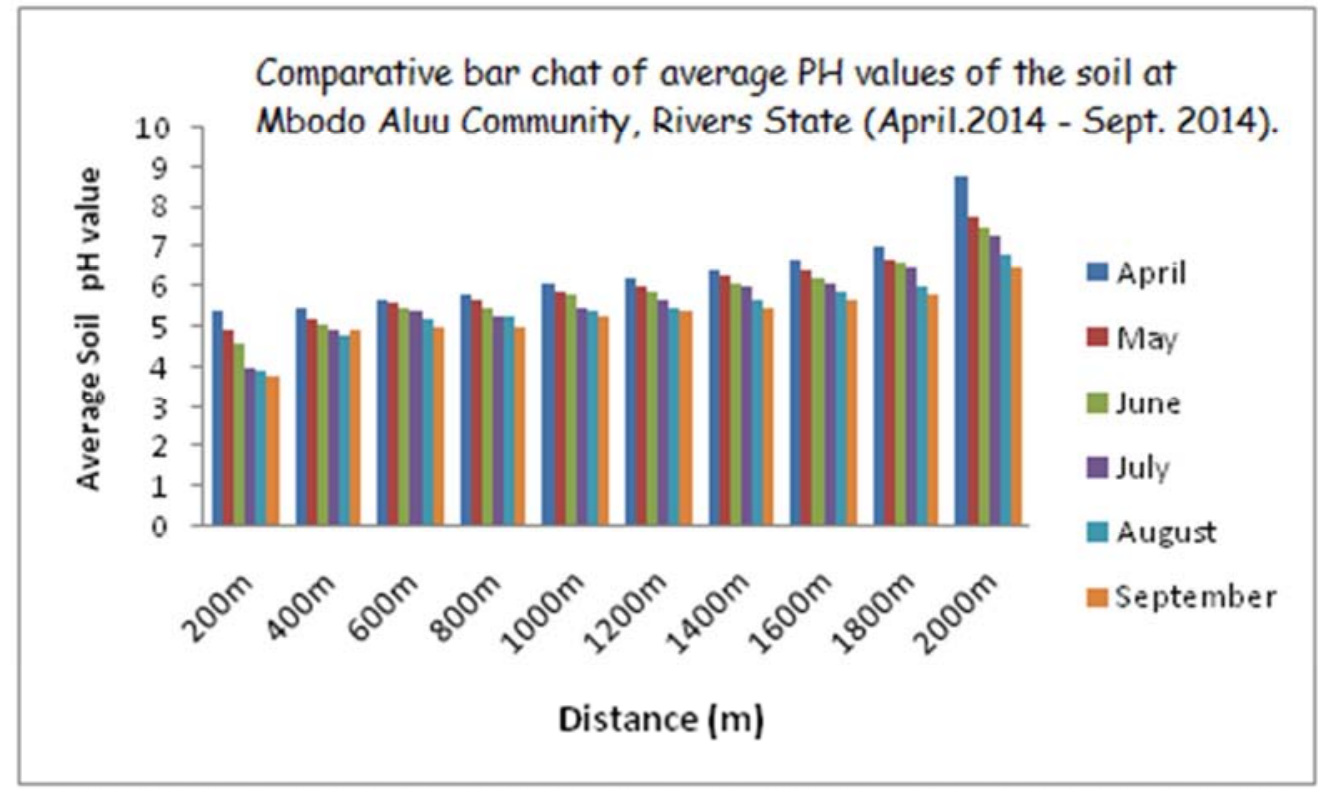

Fig. 7. Comparative Bar chat of Average pH value of the soil samples taken fromgas flaring station located at MbodoAluu Community, River State, (April. 2014 - Sept. 2014).

\section{Discussionof Result}

The result shows that the soil and rain water were acidic at distances close to the gas flaring stations. The level of acidity decreased as we moved away from the flaring stations. The rate of decrease of acidity deferred from one station to another. The low $\mathrm{pH}$ values recorded at distances close to the flare stations could be attributed to the acidic oxides produced by the flared gas. The acid rain produced by gas can cause damage to fish and other aquatic animals. Most fish eggs will not harsh at $\mathrm{pH}$ values lower than 5 . Furthermore, some adult fish cannot survive at $\mathrm{PH}$ values lower than 5 . The biodiversity is adversely affected as lakes and rivers become more acidic. The normal value of rain water is considered to be 5.6, below which the rain water is said to be acidic. It can therefore be seen that most parts of the area under investigation actually experienced acid rain and the soil was also acidic. This partly explains the prevalence of water borne diseases and the massive destruction of aquatic life recorded in these communities. However, on a few occasions, $\mathrm{pH}$ values were greater than 5.6 for rainwater samples collected from some locations. Some of the general effects of the gas flaring at OgbaEgbema-Ndomi, Eneka, Obio-Akporand Omokuincludes, stunted growth and red leaves observed in the cassava, 
plantain, palm trees, yams and other crops that were planted close to the flaring stations. It was also observed that, majority of the inhabitants who are farmers in Ogba-EgbemaNdomi, Eneka, Obio-Akpor and Omoku Communities always migrate to communities that do not flare gas for settlement in order to meet up with their farming profession.

\section{Conclusion}

The result obtained in this work shows that the $\mathrm{PH}$ value for rain water and the soil PH decreased as we moved away from all the gas flaring stations. The $\mathrm{pH}$ values actually changed from extreme acid (3.5 - 4.4) to moderate alkaline $(7.9-8.4)$ as we movedaway from the gas flaring points. This is expected because of the reaction which takes place in the atmosphere when carbon dioxide $\left(\mathrm{CO}_{2}\right)$ and carbon mono oxide $(\mathrm{CO})$ and other dangerous gases are released into the atmosphere. The result of this is the formation of acid rain which has dangerous consequences on the environment and on the plants and animals, with the resultant health implications.

\section{References}

[1] Abdulkareem, A. D., Odigure, J. O \&Benege, S. (2010): Predictive Model for Pollutant Dispersion from Gas Flaring: A Case Study of Oil Producing Area in Nigeria. Journal of Energy Sources, Part A, 1004-1015. ISSN 1556-7036.

[2] Anee, J., 2004. Oil of Poverty in the Niger Delta. A Publication of the Africa. Network for Environment and Economic Justice. Retrieved from: www.fao.org/docrep/003/x8346E/x8346e02.htmp1-10.

[3] Ansalem, O. A. (2013): Negative Effects of Gas Flaring, the Nigerian Experience. Journal of Environmental Pollution and Human Health, 1(1): 6-8.

[4] Avwiri, G O; Nte, F: Environmental sound quality of some selected flow Stations in the Niger delta of Nigeria; Journal of
Applied Sciences and Environmental Management World Bank assisted National Agricultural Research Project (NARP) - University of Port Harcourt ISSN: 1119-8362Vol. 7, Num. 2, 2003, pp. 75-77

[5] Awosika, L. F. (1995) Impacts of Global Climate Change and Sea Level Rise on Coastal Resources and Energy Development in Nigeria. In: Umolu, J. C., (Ed.), Global Climate Change: Impact on Energy Development. DAMTECH Nigeria Ltd., Nigeria.

[6] Ewona, I. O., Osang, J. E, Obi, E. O., Udoimuk A. B., Ushie, P. O.: Air Quality And Environmental Health In Calabar, Cross River State, Nigeria: (2013): IOSR Journal Of Environmental Science, Toxicology And Food Technology (IOSR-JESTFT) e-ISSN: 2319-2402, p- ISSN: 2319-2399. Volume 6, Issue 6 (Nov. - Dec. 2013), PP 55-65 www.iosrjournal.org

[7] FAO, 2008. Expert Meeting on Global Perspectives on Fuel and Food Security: Technical Report, 18-20 February, Rome.

[8] Jike, T. V, 2004. Environmental Degradation, Social Disequilibrum and the Dilemma of Sustainable Development in the Niger Delta of Nigeria. J. Black Stud, 34(5): 686-701.

[9] Nyong, A.; Adesina, F and OsmanElasha, B (2007). The Value of Indigenous Knowledge in Climate Change and Adaptation Strategies in the African Sahel. Journal of Mitigation, Adaptation and Strategic Global Change, Vol. 12, 787-789.

[10] Obi, E. O., Osang, J. E., Ewona, I. O., Udoimuk A. B.,Kamgba, F. A. (2013):, Environmental health Effect and Air Pollution from cigarette smokers in Cross River State, Nigeria;www.iosrjournal.org

[11] Penner, J. E. (1999) Aviation and global atmosphere, Inter governmental parley on climate change, Cambridge University Press, Cambridge, UK, pp 2-4, 1999.

[12] U. S. Natural Resource Conservation Service (NRCS). Washington, DC. "Soil Survey Programs" 2009.

[13] Yusuf, R. O. \& Oyewunmi, M. O. (2008) Qualitative Assessment of Methane Generation Potential from Municipal Solid Wastes: A case study. Environmental Research Journal, 2(4): 138-144. 